\title{
PENGARUH SOCIAL IDENTITY, EWOM, PERCEIVED RISK, DAN TRUST TERHADAP PURCHASE INTENTION DAN DAMPAKNYA TERHADAP PURCHASE DECISION PADA E-COMMERCE
}

\author{
Tessa Handra \\ Universitas Multimedia Nusantara \\ tessa.handra@lecturer.umn.ac.id \\ Felix Sutisna \\ Universitas Multimedia Nusantara \\ felix.sutisna@lecturer.umn.ac.id
}

\begin{abstract}
This study was designed to test empirical truths between two or more research variables that have been formulated in the hypothesis. The research variables used were social identity, EWOM, perceived risk, trust, purchase intention, and purchase decision. Exogenous variables in this study are social identity, EWOM, and perceived risk. Endogenous variables in this study are trust, purchase intention, and purchase decision. Methods of collecting data using questionnaires and data analysis methods using partial least square. The results of the study concluded that hypothesis 4 and 5 was not significant. There was no effect of perceived risk on trust and there was no effect of perceived risk on purchase intention.
\end{abstract}

Keywords: Social Identity, EWOM, Perceived Risk, Trust, Purchase Intention, Purchase Decision.

\begin{abstract}
ABSTRAK
Penelitian ini dirancang untuk menguji kebenaran empiris antara dua atau lebih variabel penelitian yang telah dirumuskan dalam hipotesis. Variabel zpenelitian yang digunakan adalah identitas sosial, EWOM, persepsi risiko, kepercayaan, niat membeli, dan keputusan pembelian. Variabel eksogen dalam penelitian ini adalah identitas sosial, EWOM, dan persepsi risiko. Variabel endogen dalam penelitian ini adalah kepercayaan, niat membeli, dan keputusan pembelian. Metode pengumpulan data menggunakan kuesioner dan metode analisis data menggunakan partial least square. Hasil penelitian menyimpulkan bahwa hipotesis 4 dan 5 tidak signifikan. Tidak ada pengaruh persepsi risiko terhadap kepercayaan dan tidak zada pengaruh persepsi risiko terhadap niat membeli.
\end{abstract}

Kata kunci: Identitas Sosial, EWOM, Persepsi Resiko, Kepercayaan, Niat Membeli, Keputusan Pembelian. 


\section{PENDAHULUAN}

Zaman sekarang ini transaksi antar pedagang dan pembeli tidak lagi harus bertatap muka, semua bisa dilakukan di mana saja dan kapan saja. Kemajuan dan kemutakhiran teknologi sekarang ini mempengaruhi gaya hidup konsumen luas. Dimulai dari bidang komunikasi yaitu munculnya berbagai handphone pintar, lalu bermunculan media sosial dan youtube dan yang sekarang banyak dilirik para pebisnis di Indonesia yaitu $e$ commerce. E-commerce adalah suatu proses berbisnis dengan menggunakan teknologi elektronik yang menghubungkan antara perusahaan, konsumen dan konsumen dalam bentuk transaksi elektronik dan pertukaran/penjualan barang, servis, dan informasi secara elektronik. E-commerce akan sangat membantu sekali dalam menghemat waktu, biaya dan tenaga bagi penjual dan dari sisi pembeli, pembeli akan dimudahkan untuk mencari segala kebutuhan yang diperlukan dengan masuk ke web e-commerce tersebut maka akan banyak iklan yang menawarkan produk-produk dari penjual. Selain itu keuntungan bagi pembeli dapat melakukan perbandingan harga dan ragam jenis barang serta tidak perlu lagi mengeluarkan waktu, biaya dan tenaga untuk menemukan barang kebutuhan semua sudah digantikan dengan e-commerce. Perkembangan e-commerce di Indonesia begitu cepat dan berkembang sangat luas, angka penjualan e-commerce tersebut juga melihatkan tandatanda yang ke arah positif. Hal ini semakin didukung dengan munculnya berbagai e-commerce seperti Tokopedia, Shopee, Blibli, Bukalapak, JD.id dan e-commerce lainnya. Selain itu perkembangan e-commerce di Indonesia masih menjadi bisnis yang sangat menguntungkan. Semakin banyaknya e-commerce yang ada di Indonesia akan semakin memudahkan dan memberikan banyak pilihan bagi masyakarat Indonesia dalam membeli barang. Selan itu konsumen juga semakin terbantu dalam mendapatkan 
informasi baik harga, kualitas, dan promo. Namun untuk menjadi $e$ commerce pilihan banyak orang perlu usaha dan performa yang baik dari e-commerce dalam melayani konsumen Indonesia. Dalam menentukan pemilihan hingga pembeli memutuskan pembelian di e-commerce yang akan digunakan, konsumen akan mengumpulkan banyak informasi sebagai bahan pertimbangan untuk membuat keputusan pembelian. Oleh karena itu analisis mengenai keputusan pembelian sangat dibutuhkan untuk menjawab masalah faktor apa saja yang mempengaruhi konsumen dalam memutuskan membeli pada salah satu e-commerce. Untuk menganalisis permasalahan keputusan pembelian maka pendekatan yang dapat digunakan adalah pendekatan theory of planned behavior (TPB) yang mempunyai asumsi bahwa suatu perilaku manusia didahului oleh niat atau kepentingan yaitu perlu dilakukan atau tidak dilakukan perilaku. Dengan demikian, niat beli dan keputusan aktual membeli memiliki hubungan yang proporsional. Beberapa penelitian mendukung penelitian ini yaitu penelitian Endhar et al. (2016), Sony (2016), Sanda (2017), Hana, et al. (2016), Dwi dan Mahendra (2013). Berdasarkan beberapa penelitian terdahulu maka penelitian ini mengambil variabel social identity, EWOM, perceived risk, trust, dan purchase intention sebagai variabel yang mempengaruhi purchase decision. Oleh karena itu tujuan penelitian ini adalah menganalisis pengaruh social identity, EWOM, perceived risk, trust, dan purchase intention terhadap purchase decision. Gunakan tabel dan gambar dengan penyesuaian terhadap panjang lebar kolom. Pada halaman terakhir makalah Anda, atur panjang lebarnya agar sama besar. Gunakan tanda hubung otomatis dan pemeriksa ejaan (bila tersedia). Tiap kolom diatur rata kiri-kanan. Gunakan tabel dan gambar dengan penyesuaian terhadap panjang lebar kolom. Pada halaman terakhir makalah Anda, atur panjang lebarnya agar sama besar. Gunakan tanda hubung otomatis dan pemeriksa ejaan (bila tersedia). 
Tiap kolom diatur rata kiri-kanan. Gunakan tabel dan gambar dengan penyesuaian terhadap panjang lebar kolom. Pada halaman terakhir

\section{TELAAH LITERATUR}

Keputusan Pembelian

$\begin{array}{llr}\text { Keputusan } & \text { Pembelian } & \text { (Purchase } \\ \text { decision), } & \text { merupakan } & \text { proses } \\ \text { dimana } & \text { konsumen } & \text { membuat } \\ \text { keputusan } & \text { untuk membeli } & \text { berbagai }\end{array}$
produk dan merek yang dimulai dengan pengenalan kebutuhan, pencarian informasi,evaluasi informasi, membuat pembelian dan kemudian mengevaluasi keputusan setelah membeli. Beberapa faktor yang berasal dari lingkungan seperti budaya, kelas sosial, pengaruh kelompok dan keluarga dapat mempengaruhi proses pengambilan keputusan seseorang. Adapun beberapa hal yang dapat mempengaruhi keputusan pembelian seperti sumber daya konsumen, motivasi, dan keterlibatan, pengetahuan, sikap dan kepribadian serta gaya hidup dan demografi (Engel et al,1995). Keputusan pembelian adalah pengambilan keputusan oleh makalah Anda, atur panjang lebarnya agar sama besar. Gunakan tanda hubung otomatis dan pemeriksa ejaan (bila tersedia).

konsumen untuk melakukan pembelian suatu produk diawali oleh adanya kesadaran atas pemenuhan kebutuhan dan keiinginan. Konsumen sadar akan kebutuhan suatu produk yang menjadi jawaban atas masalah yang dihadapi konsumen, tinggal produk mana yang harus dibeli. Pemilihan produk berdasarkan informasi-informasi yang digali oleh konsumen melalui berbagai media. Setelah itu konsumen mengevaluasi dan mempertimbangkan produk yang akan dibeli nanti berdasarkan informasi tersebut sehingga akhirnya memutuskan suatu produk yang tepat sesuai kebutuhan dan manfaat produk tersebut. Menurut Schiffman dan Kanuk (2004) keputusan pembelian sebagai pemilihan dari dua atau lebih alternatif pilihan keputusan pembelian. Konsumen harus menentukan pilihan dari berbagai alternatif yang ada. 
Intensi Pembelian

Purchase intention atau minat beli menurut Assael (1998) merupakan kecenderungan konsumen untuk membeli suatu merek atau mengambil tindakan yang berhubungan dengan pembelian yang diukur dengan tingkat kemungkinan konsumen melakukan pembelian. Menurut Kotler \& Keller (2006), purchase intention adalah seberapa besar kemungkinan konsumen membeli suatu merek atau seberapa besar kemungkinan konsumen untuk berpindah dari satu merek ke merek lainnya. Schiffman dan kanuk (2004), mengemukakan bahwa minat membeli merupakan pikiran yang timbul karena adanya perasaan tertarik dan ingin memiliki terhadap suatu barang atau jasa yang diharapkan. Penulis memiliki definisi sendiri tentang purchase intention yaitu suatu keadaan yang dimana seseorang sadar untuk bertahan hidup harus memenuhi segala kebutuhan pokoknya dengan melakukan pembelian untuk melanjutkan hidupnya

\section{Electronic Word of Mouth}

Electronic word of Mouth merupakan pernyataan positif atau negatif yang dibuat oleh pelanggan potensial, pelanggan aktual dan mantan pelanggan tentang produk atau perusahaan melalui internet (Malik et al., 2013). Menurut Hennig-Thurau (2004), electronic word of mouth (EWOM) merujuk pada pernyataan positif atau negatif dari potential, aktual atau konsumen pendahulu mengenai suatu produk atau perusahaan via internet. Web telah menciptakan kesempatan kepada EWOM berkomunikasi melalui berbagai macam media seperti forum diskusi, electronic bulletin board, newsgroup, blog, dan social networking (Goldsmith, 2006). Menurut Hennig-Thurau et al., (2004), EWOM merupakan bentuk komunikasi pemasaran yang berisi tentang pernyataan positif atau negatif yang dilakukan pelanggan potensial, pelanggan maupun mantan pelanggan tentang suatu produk atau perusahaan, yang tersedia bagi banyak orang atau lembaga melalui media internet. 
EWOM memiliki jangkauan yang sangat luas dan kecepatan dalam penyebaran informasinya sangat cepat dan bahkan tak terkendali karena menggunakan berbagai macam media diinternet seperti web, blog, media sosial, youtube, dan twitter. berbeda dengan word of mouth yang traditional yang hanya mengandalkan rekomendasi dari orang-orang yang kita kenal saja atau dari komunitas yang kita miliki dan disampaikan secara langsung melalui tatap muka atau berkomunikasi secara langsung dan tidak tersebar di media internet. Informasi dalam bentuk EWOM tidak perlu ada pertukaran informasi antar sesama pembaca atau komunikator hadir. Contohnya, pengguna forum dapat membaca dan menulis komentar orang lain setelah topik pembicaraan dibuat. EWOM lebih tetap dan mudah diakses kapan saja dan dimana saja.

Hampir sebagian besar EWOM ditulis dalam bentuk teks yang ditampilkan di internet diarsipkan sehingga akan tersedia dalam waktu yang tidak terbatas. Peneliti dapat dengan mudah mengambil dalam jumlah yang besar pesan yang ada di EWOM secara online dan menganalisis karakteristik mereka seperti jumlah kata sentimental yang digunakan posisi pesan, gaya pesan, dan sejenisnya. Namun ada kekurangan dari EWOM dimana tidak dapat melakukan penilaian kreadibilitas komunikator melalui sistem reputasi online. Menurut Goldsmith and Horowitz (2006), berpendapat bahwa di dunia online, ada bermacam-macam cara dimana konsumen dapat bertukar informasi. Pengguna internet dapat melakukan Electronic word of mouth melalui berbagai saluran online, termasuk blog, mikroblog, email, situs ulasan (review) konsumen, forum, komunitas konsumen virtual, dan situs jejaring sosial. Penulis berpendapat bahwa EWOM adalah suatu pengalaman yang dirasakan oleh pengguna baik itu produk maupun jasa baik pengalaman yang mereka dapat adalah pengalaman baik atau buruk dari produk atau jasa tersebut yang disebarluaskan oleh pengguna menggunakan media internet yang dapat diakses oleh 
semua orang yang mempunyai akses internet.

\section{Identitas sosial}

Identifikasi dengan kelompok sosial adalah keadaan psikologis yang sangat berbeda dari kategori sosial tertentu dan memiliki hasil evaluasi diri yang penting. secara keseluruhan, identitas sosial dapat mendukung ketika dalam keadaan tertekan. Teori ini dikemukakan oleh Dholakia et al (2004). Menurut Tajfel (1982), identitas sosial adalah bagian dari konsep diri seseorang yang berasal dari pengetahuan mereka tentang keanggotaan dalam suatu kelompom sosial bersamaan dengan signifikansi nilai dan emosional dari keanggotaan tersebut. Identitas merupakan persepsi atas anggota kelompok terhadap kelompoknya yang dianggap memiliki kesamaan dan membentuk suatu ikatan emosional antar anggota kelompok dan kelompok itu sendiri.Hogg \& Reid (2006), mengartikan bahwa identitas sosial dasar untuk sejumlah fenomena komuni-katif yang nyata, menjelaskan bagaimana norma kelompok yang direpresentasikan sebagai kognitif yang tergantung pada konteks prototipe yang menangkap sifat khas kelompok.Menurut Padilla \& Perez (2003), teori identitas sosial menyatakan bahwa individu berpikir, merasa, dan bertindak sebagaimana yang dilakukan oleh anggota kelompok yang diikuti. Pendapat lain menyatakan bahwa individu memutuskan bergabung dengan kelompok sosial yang sesuai dengan dirinya dan dapat meningkatkan status sosialnya. Bernad et al (2016). Penulis memiliki pengertian lain tentang identitas sosial yaitu Sebuah komunitas yang memiliki kesamaan baik hobby, pekerjaan, gaya hidup ataupun kesamaan-kesamaan tertentu yang bergabung menjadi satu dan membuat suatu identitas sendiri baik diakui atau tidak diakui oleh masyarakat luas.

\section{Peneriman Risiko}

Oglethorpe dan Monroe (1994) mengekumakan bahwa konsumen menghadapi ketidakpastian dan konsekuensi-konsekuensi negatif yang mungkin diterima atas pembelian suatu produk atau jasa. 
Konsumen giat mencari informasi tambahan ketika dihadapkan pada pembelian yang berisiko tinggi. Lui dan Jamieson (2003) menyatakan tingkat risiko dalam berbelanja secara online tergantung pada persepsi konsumen dalam memperkirakan tinggi rendahnya risiko yang akan dialami ketika menggunakan internet untuk berbelanja. Konsumen memiliki persepsi resiko yang lebih tinggi ketika melakukan pembelian secara online jika dibandingkan ketika mereka melakukan pembelian melalui toko. (Suresh dan Shashikala, 2011). Ada pendapat lain yang mengatakan bahwa persepsi akan resiko dinilai sebagai tingkat anggapan pelanggan akan hasil negatif yang mungkin terjadi ketika melakukan transaksi secara online (Featherman and Pavlou, 2002). Dalam melakukan pembelian secara onlineada tiga macam resiko yang akan dihadapi oleh konsumen yaitu risiko produk, risiko transaksi, dan risiko psikologis. Risiko produk mengacu pada ketidakpastian bahwa produk yang dibeli secara online tidak sesuai dengan harapan karena tidak pernah melihat langsung secara fisik atau memegangnya secara langsung. Risiko transaksi adalah resiko ketidakpastian dalam pembayaran apakah uang yang dikirim sampai pada orang yang tepat atau tidak. Risiko psikologis adalah rasa ketakutan dan khawatir yang timbul selama proses pembelian sampai proses pengiriman barang tersebut sampai ditangan konsumen. Kondisi ini menghasilkan pengambilan keputusan yang kompleks. Konsumen secara tidak langsung akan melakukan evaluasi secara detail terhadap produk dan merek yang menjadi pesaing dari produk tersebut. Penulis mengartikan Perceived of risk adalah persepsi atau pemikiran tentang risiko yang akan dialami oleh konsumen, suatu ketidakpastian dan konsekuensikonsekuensi yang bisa terjadi yang akan diterima oleh konsumen.

Kepercayaan

Trust diartikan sebagai kesediaan mengandalkan kemampuan, intergritas dan motivasi pihak lain untuk bertindak dalam rangka memuaskan kebutuhan dan kepentingan seseorang sebagaimana disepakati bersama secara implesit 
maupun eksplesit (Sheth dan Mittal, 2004). Trust atau kepercayaan dipandang sebagai persepsi akan kehandalan dari sudut pandang konsumen didasarkan pada pengalaman, atau lebih pada urutan-urutan transaksi atau interaksi yang dicirikan oleh terpenuhinya harapan akan kinerja produk dan kepuasaan. Guillen et al. (2003), mendefinisikan trust (kepercayaan merek) sebagai suatu perasaan aman yang dimiliki konsumen akibat dari interaksinya dengan sebuah merek, yang berdasarkan persepsi bahwa merek tersebut dapat diandalkan dan bertanggung jawab atas kepentingan dan keselamatan dari konsumen. Pengalaman menjadikan sumber bagi konsumen bagi terciptanya suatu kepercayaan pada suatu produk atau merek yang timbul secara alami yang bisa disebabkan karena keinginan yang dimiliki konsumen hanya bisa dijawab oleh produk atau merek tersebut. Ini yang membuat kepercayaan itu tumbuh sehingga konsumen tidak akan beralih lagi keproduk lain karena kepercayaan akan merek dan produk tersebut memiliki kemampuan untuk menjawab kebutuhan konsumen bahkan memberikan lebih dari konsumen butuhkan. Kepercayaan adalah rasa yang timbul secara alami berdasarkan pengalaman seseorang yang dimana produk atau jasa yang dipilih oleh konsumen dapat diandalkan dan dapat dipertanggungjawabkan.

Pengaruh purchase intention terhadap purchase decision

Minat beli mampu menghasilkan keputusan pembelian dari minat yang dialami oleh konsumen. Pada tahapan timbulnya minat, konsumen menyadari bahwa mereka menyukai produk tertentu dan ingin memiliki produk tersebut sehingga apabila keyakinan terhadap produk positif maka akan menimbulkan keputusan untuk melakukan pembelian (Endhar et al., 2016). Ari et al (2013) menyimpulkan bahwa minat beli merupakan variabel yang mempengaruhi keputusan pembelian. Hasil yang serupa juga disimpulkan oleh penelitian Tri et al (2013). Berdasarkan uraian tersebut maka hipotesis penelitian: 
Hipotesis 1: Terdapat pengaruh purchase intention terhadap purchase decision.

Pengaruh EWOM terhadap trust EWOM mempengaruhi kepercayaan konsumen dalam membuat keputusan pembelian.

Semakin positif informasi yang disebarluaskan dari konsumen kepada konsumen lainnya maka akan menimbulkan tingkat kepercayaan yang baik. Konsumen cenderung mempercayai opini dari konsumen lain yang telah mengkonsumsi produk. Opini yang positif cenderung meningkatkan kepercayaan konsumen terhadap kinerja produk (Syafaruddin et al., 2016). Penelitian Annisa dan Tony (2016) menemukan bahwa EWOM berpengaruh terhadap trust. Hasil ini sesuai dengan penelitian Hatane dan Adi (2014). Berdasarkan uraian tersebut maka hipotesis penelitian:

Hipotesis 2: Terdapat pengaruh EWOM terhadap trust

Pengaruh social identity terhadap trust

Identitas sosial pada komunitas yang kuat dapat mengarahkan individu kepada anggapan bahwa anggota komunitas mereka lebih bisa diandalkan dan dapat memperlihatkan evaluasi yang positif. Oleh karena itu anggota yang memiliki rasa memiliki komunitas dan memahami dirinya adalah bagian dari komunitas akan memiliki rasa kepercayaan yang lebih tinggi kepada komunitas dan anggota di dalamnya. Dengan demikian tingkat identitas sosial diyakini memiliki pengaruh terhadap tingkat kepercayaan yang dimiliki anggota komunitas (Sony, 2016). Penelitian Rahmania (2015) menyimpulkan bahwa terdapat pengaruh positif identitas sosial terhadap kepercayaan. Cindy (2014) menyimpulkan bahwa tidak terdapat pengaruh identitas sosial terhadapkepercayaan. Berdasarkan uraian tersebut maka hipotesis penelitian: Hipotesis 3: Terdapat pengaruh social identity terhadap trust

Pengaruh perceived risk terhadap trust

Persepsi risiko mempengaruhi kepercayaan konsumen. semakin tinggi risiko dalam melakukan pembelian online maka konsumen 
akan semakin tidak percaya terhadap situs jual beli online tersebut. Beberapa risiko yang ada dalam melakukan pembelian online seperti resiko terhadap metode pembayaran, resiko terhadap penyalahgunaan informasi data pribadi, dan juga risiko terhadap ketidaksesuaian barang yang diterima dengan barang yang dipasang di situs jual beli (Sanda, 2017). Penelitian Awliya et al (2014) menemukan bahwa terdapat pengaruh negatif perceived risk terhadap trust sejalan dengan hasil penelitian Hana, et al. (2016). Berdasarkan uraian tersebut maka hipotesis penelitian:

Hipotesis 4: Terdapat pengaruh perceived risk terhadap trust

Pengaruh perceived risk terhadap purchase intention

Semakin tinggi persepsi risiko maka akan menyebabkan seseorang mempunyai ketakutan lebih tinggi saat bertransaksi online, begitu juga sebaliknya. Persepsi terhadap risiko diprediksi akan berpengaruh negatif terhadap niat individu untuk menggunakan online shop. Persepsi risiko menjadi salah satu komponen penting dalam pemrosesan informasi yang dilakukan oleh konsumen. Konsumen terdorong untuk mencari tambahan informasi ketika dihadapkan pada pembelian produk dengan risiko tinggi. Persepsi risiko yang rendah akan menyebabkan tingginya minat untuk bertransaksi secara online, dan juga sebaliknya persepsi risiko yang tinggi akan menyebabkan rendahnya minat untuk bertransaksi secara online (Ratna et al, 2016). Penelitian Hana, et al. (2016) menyimpulkan bahwa terdapat pengaruh negatif perceived risk terhadap purchase intention sesuai dengan penelitian Arif dan Noor (2018). Berdasarkan uraian tersebut maka hipotesis penelitian:

Hipotesis 5: Terdapat pengaruh perceived risk terhadap purchase intention.

Pengaruh trust terhadap purchase intention

Trust yang semakin tinggi tentu akan dapat dijadikan ukuran untuk menumbuhkan purchase intention secara online. Semakin tinggi trust maka semakin tinggi purchase intention. Trust secara 
positif mempengaruhi niat untuk berbelanja secara online karena konsumen yakin bahwa perusahaan mampu menjalankan kegiatan online-nya (karena kompetensi) dan dapat mengirimkan produk-produk yang dibeli kepada konsumen. Jika konsumen mempercayai online store yang disediakan oleh perusahaan, maka hal tersebut memungkinkan mereka meningkatkan niatnya untuk melakukan pembelian secara online. Pemahaman ini secara

\section{METODOLOGI PENELITIAN}

Penelitian ini didesain untuk menguji kebenaran empiris antara dua atau lebih variabel penelitian yang telah dirumuskan dalam hipotesis. Variabel penelitian yang digunakan adalah social identity, EWOM, perceived risk, trust, purchase intention, dan purchase decision. Variabel eksogen dalam penelitian ini adalah social identity, EWOM, dan perceived risk. Variabel endogen dalam penelitian ini adalah purchase intention dan purchase umum mengontrol transaksi online yang berpengaruh positif terhadap niat konsumen untuk melakukan pembelian (Dwi dan Mahendra, 2013). Penelitian Arif dan Noor (2018) menyimpulkan bahwa terdapat pengaruh positif dan signifikan trust terhadap purchase intention. Hasil ini sesuai dengan penelitian Antoni dan Meyzi (2017). Berdasarkan uraian tersebut maka hipotesis penelitian:

Hipotesis 6: Terdapat pengaruh trust terhadap purchase intention

decision. Metode pengumpulan data menggunakan kuesioner dan metode analisis data menggunakan partial least square. Sampel penelitian sebanyak 100 responden yang merupakan konsumen $e$ commerce $X$ selama periode bulan Desember 2020. Pengambilan 100 responden ini didasarkan oleh pendapat Agus (2015) yang menyatakan bahwa dalam penggunaan partial least square sebaiknya sampel yang digunakan minimal sebanyak 100 observasi 


\section{HASIL DAN PEMBAHASAN}

\section{Pengujian Validitas}

Menurut Agus (2015) pengujian validitas konvergen yang dikoreksi dinyatakan valid apabila nilai loading factor lebih besar atau sama dengan 0,3. Sedangkan discriminant validity dilihat dari nilai AVE dan dinyatakan valid apabila lebih besar atau sama dengan 0,5 (Agus, 2015). Hasil pengujian validitas konvergen dapat dilihat pada tabel berikut

Tabel 1 Output Smartpls untuk Uji Validitas

\begin{tabular}{|c|c|c|c|c|c|c|}
\hline & EWOM & Perceived Risk & Purchase Decision & Purchase Intention & Social Identity & Trust \\
\hline EW1 & 0.922 & & & & & \\
\hline EW2 & 0.768 & & & & & \\
\hline EW3 & 0.921 & & & & & \\
\hline EW4 & 0.791 & & & & & \\
\hline P01 & & & 0.966 & & & \\
\hline PD2 & & & 0.827 & & & \\
\hline PD3 & & & 0.963 & & & \\
\hline PII & & & & 0.936 & & \\
\hline$P 12$ & & & & 0.726 & & \\
\hline $\mathrm{PB}$ & & & & 0.952 & & \\
\hline PR1 & & 0.836 & & & & \\
\hline PR2 & & 0.736 & & & & \\
\hline PR3 & & 0.818 & & & & \\
\hline SII & & & & & 0.836 & \\
\hline SI & & & & & 0.788 & \\
\hline$S B$ & & & & & 0.857 & \\
\hline $\mathrm{T} 1$ & & & & & & 0.939 \\
\hline $\mathrm{T} 2$ & & & & & & 0.746 \\
\hline T3 & & & & & & 0.958 \\
\hline
\end{tabular}

Butir pernyataan EWOM memiliki nilai loading factor tertinggi 0,922 dan terendah 0,768. Butir pernyataan perceived risk memiliki nilai loading 
factor tertinggi 0,836 dan terendah 0,736. Butir pernyataan purchase decision memiliki nilai loading factor tertinggi 0,966 dan terendah 0,827 . Butir pernyataan purchase intention memiliki nilai loading factor tertinggi 0,952 dan terendah 0,726. Butir pernyataan social identity memiliki nilai loading factor tertinggi 0,857 dan terendah 0,788. Butir pernyataan trust memiliki nilai loading factor tertinggi 0,958 dan terendah 0,746 . Setelah diuji convergent validity selanjutnya diuji discriminant validity dengan melihat nilai AVE (Agus, 2015).

Tabel 2 Average Variance Extracted (AVE) dan Cronbach Alpha

\begin{tabular}{|l|c|c|}
\hline \multicolumn{1}{|c|}{ Variabel } & AVE & $\begin{array}{c}\text { Cronbach's } \\
\text { Alpha }\end{array}$ \\
\hline EWOM & 0,728 & 0,873 \\
\hline Perceived Risk & 0,637 & 0,717 \\
\hline Purchase Decision & 0,848 & 0,908 \\
\hline Purchase Intention & 0,77 & 0,844 \\
\hline Social Identity & 0,684 & 0,771 \\
\hline Trust & 0,785 & 0,858 \\
\hline
\end{tabular}

Gambar 1 Output SmartPLS

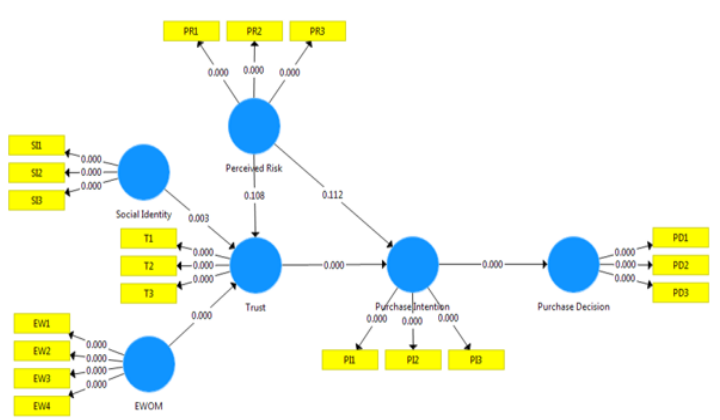


Tabel 3 Rangkuman Pengujian Hipotesis

\begin{tabular}{|c|c|c|c|c|c|}
\hline & Oniginal Sampl... & Sample Mean (... & Standard Devid... & $\operatorname{TStatistics}\left(10_{\mathrm{m}}\right.$ & PValues \\
\hline EWOM $\rightarrow$ Trust & 0.421 & 0.420 & 0.068 & 6.201 & 0.000 \\
\hline Perceved Risk $\rightarrow$ Purchose Intention & $\cdot 0.057$ & .0 .059 & 0.036 & 1592 & 0.112 \\
\hline Percéved Risk. $\rightarrow$ Trust & 0.191 & .0 .196 & 0.119 & 1.609 & 0.108 \\
\hline Purchase intention $\rightarrow$ Purchase Decision & 0981 & 0981 & 0.005 & 1860.27 & 0.000 \\
\hline Sociald dentity-) Trust & 0.304 & 0.301 & 0.102 & 2970 & 0.003 \\
\hline Trust $\rightarrow$ Purchase Intention & 0940 & 0938 & 0.032 & 20.274 & 0.000 \\
\hline
\end{tabular}

Berdasarkan tabel 3 nilai p-value untuk hipotesis 1 sebesar sebesar $0,000<0,05$ artinya terdapat pengaruh purchase intention terhadap purchase decision. Nilai p-value untuk hipotesis 2 zsebesar $0,000<$ 0,05 artinya terdapat pengaruh EWOM terhadap trust. Nilai $p$-value untuk hipotesis 3 sebesar sebesar $0,003<0,05$ artinya terdapat pengaruh social identity terhadap

\section{SIMPULAN}

Terdapat pengaruh purchase intention terhadap purchase decision. Hasil ini sesuai dengan penelitian Endhar et al (2016), Ari et al (2013), dan Tri et al (2013). Minat beli mampu menghasilkan keputusan pembelian dari minat yang dialami oleh konsumen. Pada tahapan timbulnya minat, konsumen menyadari bahwa trust. Nilai $p$-value untuk hipotesis 4 zsebesar $0,108>0,05$ artinya tidak terdapat pengaruh perceived risk terhadap trust Nilai $p$-value untuk hipotesis 5 sebesar sebesar 0,112> 0,05 artinya tidak terdapat pengaruh perceived risk terhadap purchase intention. Nilai p-value untuk hipotesis 6 sebesar sebesar $0,112<$ 0,000 artinya terdapat pengaruh trust terhadap purchase intention

mereka menyukai produk tertentu dan ingin memiliki produk tersebut sehingga apabila keyakinan terhadap produk positif maka akan menimbulkan keputusan untuk melakukan pembelian. Meyediakan produk yang banyak diminati dan dibutuhkan konsumen dapat meningkatkan minat membeli sehingga dapat meningkatkan peluang keputusan membeli. Terdapat pengaruh EWOM terhadap trust. Hasil ini sesuai dengan 
penelitian Tony (2016), dan Hatane dan Adi

(2014). EWOM

mempengaruhi

kepercayaan

konsumen dalam membuat

keputusan pembelian. Semakin

positif informasi yang

disebarluaskan dari konsumen

kepada konsumen lainnya maka

akan menimbulkan tingkat

kepercayaan yang baik. Konsumen

cenderung mempercayai opini dari

konsumen lain yang telah

mengkonsumsi produk. Opini yang

positif cenderung meningkatkan

kepercayaan konsumen terhadap

kinerja produk. EWOM mewakili

opini konsumen. Oleh karena itu

meningkatkan citra positif produk

dapat meningkatkan review dan testimony positif yang dapat meyakinkan konsumen terhadap suatu produk. Terdapat pengaruh social identity terhadap trust. Hasil ini tidak sesuai dengan penelitian Sony (2016), Rahmania (2015), dan Cindy (2014). Identitas sosial pada komunitas yang kuat dapat mengarahkan individu kepada anggapan bahwa anggota komunitas mereka lebih bisa diandalkan dan dapat memperlihatkan evaluasi yang positif. Oleh karena itu anggota yang memiliki rasa memiliki komunitas dan memahami dirinya adalah bagian dari komunitas akan memiliki rasa kepercayaan yang lebih tinggi kepada komunitas dan anggota di dalamnya. Dengan demikian tingkat identitas sosial diyakini memiliki pengaruh terhadap tingkat kepercayaan yang dimiliki anggota komunitas. Menyediakan produk yang dibutuhkan komunitas tertentu merupakan suatu cara meningkatkan identitas sosial terhadap kepercayaan. E-commerce yang menyediakan hanya produk branded dapat meyakinkan konsumen bahwa produk yang dijualnya merupakan produk premium. Tidak terdapat pengaruh perceived risk terhadap trust. Hasil ini sesuai dengan penelitian Sanda (2017), Awliya et al (2014), dan Hana, et al. (2016). Hasil ini tidak signifikan disebabkan oleh konsumen yang sudah berpengalaman dalam melakukan transaksi pada $e$ commerce sehingga sudah terbentuk kepercayaan terhadap e-commerce. Umumnya memperkecil resiko 
pembelian dapat meningkatkan kepercayaan konsumen terhadap suatu e-commerce. Penyediaan layanan pengembalian uang apabila produk yang diterima tidak sesuai merupakan salah satu cara memperkecil resiko yang berdampak kepada kepercayaan konsumen. Tidak terdapat pengaruh perceived risk terhadap purchase intention. Hasil ini sesuai dengan penelitian Ratna et al (2016), Hana, et al. (2016), dan Arif dan Noor (2018). Hasil ini tidak signifikan karena promosi harga yang ditawarkan serta produk yang sangat menarik sehingga konsumen tidak terlalu memperhatikan resiko yang ada. Konsumen pada dasarnya selalu memikirkan resiko dalam membeli suatu produk.Apabila e-commerce dapat memperkecil resiko ini maka minat beli pun akan meningkat. Keamanan dalam bertransaksi online merupakan salah satu cara memperkecil resiko dalam berbelanja di e-commerce. Terdapat pengaruh trust terhadap purchase intention. Hasil ini sesuai dengan penelitian Dwi dan Mahendra (2013), Arif dan Noor (2018),
Antoni dan Meyzi (2017). Trust yang semakin tinggi tentu akan dapat dijadikan ukuran untuk menumbuhkan purchase intention secara online. Semakin tinggi trust maka semakin tinggi purchase intention. Trust secara positif mempengaruhi niat untuk berbelanja secara online karena konsumen yakin bahwa perusahaan mampu menjalankan kegiatan online-nya (karena kompetensi) dan dapat mengirimkan produk-produk yang dibeli kepada konsumen. Jika konsumen mempercayai online store yang disediakan oleh perusahaan, maka hal tersebut memungkinkan

mereka meningkatkan niatnya untuk melakukan pembelian secara online. Pemahaman ini secara umum mengontrol transaksi online yang berpengaruh positif terhadap niat konsumen untuk melakukan pembelian. Kepercayaan konsumen merupakan faktor utama dalam pembelian produk. Membuat konsumen percaya terhadap suatu produk, merek, kinerja produk harus dilakukan oleh sales. Walaupun e-commerce menjual produk secara online namun 
pembuktian ataupun testimony tenaga penjualan dapat meningkatkan kepercayaan konsumen. Konsumen akan percaya terhadap suatu produk apabila konsumen sudah memperoleh informasi mengenai

\section{DAFTAR PUSTAKA}

Agus Widarjono. (2015). Analisis statistika multivariat terapan. Yogyakarta: UPP STIM YKPN.

Annisa M. A. Dan Tony W. (2016). Pengaruh EWOM terhadap brand image dan brand trust, serta dampaknya pada minat beli produk smartphone iphone (studi pada masyarakat di Yogyakarta. Jurnal Manajemen Bisnis Indonesia, Vol. 5, No. 3. Retrieved from http://journal.student.uny.ac.i d/ojs/index.php/jmbi/article/vi ew/5030/4696.

Antoni dan Meyzi H. (2017). Pengaruh brand image dan kepercayaan merek terhadap minat beli konsumen pada produk mobil Toyota Etios Valco. JOM FISIP, Vol. 4, No. 1. Retrieved from https://jom.unri.ac.id/index.p hp/JOMFSIP/article/view/123 00/11945. produk dari pihak lain. Oleh karena itu penggunaan tenaga penjual untuk memasarkan produk dapat meningkatkan kepercayaan konsumen.

Ari, M. A. et al. (2013). Peran Minat Beli Konsumen Sebagai Mediasi Kualitas Produk terhadap Keputusan Pembelian pada Perusahaan Kue. Binus Business Review, Vol. 4, No. 1. doi: https://doi.org/10.21512/bbr.v 4i1.1125.

Arif R. M. dan Noor K. (2018). Pengaruh kepercayaan, kemudahan, dan persepsi risiko terhadap keputusan pembelian jasa Gojek di kota Semarang yang dimediasi minat beli sebagai variabel intervening. Ekobis, Vol. $19, \quad$ No. 2. doi: http://dx.doi.org/10.3065 9/ekobis.19.2.203-213.

Assael, H. (1998). Consumer Behavior and Marketing Action 6th Edition. New York: South Western College Publishing.

Awliya A. et al. (2014). Analisis pengaruh persepsi teknologi, 
persepsi resiko terhadap kepercayaan dan dampaknya terhadap kepuasan belanja online mahasiswa di Pekanbaru. Jurnal Ekonomi, Vol. 22, No. 3. doi: http://dx.doi.org/10.31258/je. 22.3.p.1-16.

Bernad, M. et al (2016). Social Identity and Social FreeRiding. European Economic Review. doi: http://dx.doi.org/10.1016/j.eu roecorev.2016.01.001.

Cindy F. T. (2014). Pengaruh identitas merek terhadap loyalitas merek melalui citra nerek dan kepercayaan merek Toyota. Jurnal Manajemen Pemasaran, Vol. 8, No. 2. doi: 10.9744/pemasaran.8.2.6269.

Dholakia, U. M. et al. (2004). A Social Influence Model of Consumer Participation in Network- and Small-GroupBased Virtual Communities. International Journal of Research in Marketing, Vol. 21. doi: https://doi.org/10.1016/j.ijres mar.2003.12.004.

Dwi P. J. A. dan Mahendra A. N. Pengaruh trust dan perceived of risk terhadap niat untuk bertransaksi menggunakan e-commerce. Jurnal Nominal, Vol. II, No. 1 . doi: https://doi.org/10.21831/nomi nal.v2i1.1646.

Endhar W. P. (2016). Pengaruh diskon terhadap minat beli serta dampaknya pada keputusan pembelian. Jurnal Administrasi Bisnis, Vol. 38, No. 2. Retrieved from http://administrasibisnis.stude ntjournal.ub.ac.id/index.php/j ab/article/view/1525/1909.

Engel, J. F. Et al. (1995). Perilaku Konsumen. Jakarta: Bina Rupa Aksara.

Featherman, M. S. and Pavlou, P. A. (2002). Predicting eservice Adoption: A Perceived Risk Facet Perspective. International Journal of Human-Computer Studies, Vol. 59. doi: https://doi.org/10.1016/S1071 -5819(03)00111-3.

Guillen, M. J. et al. (2003). Development and Validation of Brand Trust Scale. International Journal of Market Research., Vol. 45, No. $\quad 1$. doi: https://doi.org/10.1177\%2F1 47078530304500103.

Goldsmith, R. E. and Horowitz, D. (2006).

Measuring Motivations for Online Opinion Seeking, Journal of Interactive Advertising, Vol. 6, No. $2 . \quad$ doi: https://doi.org/10.1080/15252 019.2006 .10722114$.

Hana A. et al. (2016). Pengaruh past experience dan perceived risk terhadap purchase intention pada situs Rakuten.co.id di Jakarta dengan customer trust sebagai variabel mediator. Conference on Management and Behavioral 
Studies. Retrieved from http://repository.untar.ac.id/1 1931/.

Hatane S. dan Adi S. L. (2014). Anlaisis EWOM, brand image, brand trust dan minat beli produk smartphone di Surabaya. Jurnal Manajemen Pemasaran, Vol. 8, No. 2. doi:

10.9744/pemasaran.8.2.47-

54.

Hennig-Thurau, T. et al. (2004). Electronic word of mouth via consumer opinion platforms: What motivates consumers to articulate themselves on the internet. Journal of Interactive Marketing, Vol. 18, No. 1. doi:

https://doi.org/10.1002/dir.10 073.

Hogg, M. A. and Reid, S. A. (2006). Social Identity, SelfCategorization, and the Communication Group Norms. Communication Theory, Vol. 16. doi:10.1111/j.14682885.2006.00003.x.

Kotler, P. and Keller, K. L. (2006). Marketing Management. New Jersey: Pearson.

Lui, H. K. and Jamieson R. (2003). Integrating Trust and Risk Perception in Business to Consumer Electronic Commerce with Technology Acceptance Model. ECIS 2003 Proceedings. Retrieved from https://www.researchgat e.net/publication/221408744_I ntegrating_trust_and_risk_per ceptions_in_business-to consumer_electronic_commer ce_with_the_technology_acce ptance_model.

Malik, M. E. et al., (2013). Impact of Brand Image and Advertisement on Consumer Buying Behavior. World Applied Sciences Journal, Vol. 23, No. 1. doi: 10.5829/idosi.wasj.2013.23.0 1.824 .

Oglethorpe , J. E. and Monroe , K. B. (1994). Determinants of Perceived Health and Safety Risks of Selected Hazardous Products and Activities. The Journal of Consumer Affairs, Vol. 28, No. $2 . \quad$ doi: https://doi.org/10.1111/j.1745 -6606.1994.tb00855.x.

Padilla, A. M. and Perez, W. (2003). Acculturation, Social Identity, and Social Cognition: A New Perspective. Hispanic Journal of Behavioral Sciences., Vol. 25, No, 1. doi:

10.1177/0739986303251694.

Rahmania A. (2015). Pengaruh dari identity terhadap brand value, satisfaction, trust and brand loyalty. Jurnal Manajemen dan Pemasaran Jasa, Vol. 8, no. 2. Retrieved from https://trijurnal.lemlit.trisakti. ac.id/jasa/article/view/1593/1 383. 
Ratna M. R. et al. (2016). Pengaruh kepercayaan terhadap minat beli melalui persepsi risiko pada transaksi jual beli online melalui media sosial. Jurnal Ekonomi Bisnis, Vol. 21, No. 2. Retrieved from http://journal.um.ac.id/index. php/ekobis/article/view/7433/3 384.

Sanda K. S. (2017). Pengaruh ecommerce knowledge, risiko, dan teknologi terhadap kepercayaan dan niat beli online. Jurnal Ekonomi Manajemen Sumber Daya, Vol. 19, No. 2. DOI: https://doi.org/10.23917/daya saing.v19i2.5382.

Schiffman \& Kanuk. (2004). Perilaku Konsumen (edisi 7). Jakarta: Prentice Hall.

Sheth, J.N. and Mittal, B. (2004) Customer Behavior: A Managerial Perspective. 2nd Edition. New York: SouthWestern.

Sony K. (2016). Social identity, group norm, trust, and online helping behavior on Facebook-based community. Jurnal Ilmiah Manajemen, Vol. VI, No. 2. Retrieved from

https://www.researchgate.net/ publication/309662556_Social _Identity_Group_Norms_Trus
t_and_Online_Helping_Behav ior_on_Facebookbased_Community.

Suresh, A. M. and Shashikala, R. (2011). Identifying Factors of Consumer Perceived Risk toward One-commerce in India. $3 r d$ International Conference on Information and Financial Engineering IPEDR, Vol.12. Retrieved from

http://www.ipedr.com/vol12/6 1-C137.pdf.

Syafaruddin Z. (2016). Pengaruh komunikasi electronic word of mouth terhadap kepercayaan (trust) dan niat beli (purchase intention) serta dampaknya pada keputusan pembelian. Jurnal Bisnis dan Manajemen, Vol. 3, No. 1. Retrieved from https://media.neliti.com/medi a/publications/75271-IDnone.pdf.

Tajfel, H. (1982). Social Psychology of Intergroup Relations. Annual Review Psychology, Vol. 33, No. 1. doi:

https://doi.org/10.1146/annur ev.ps.33.020182.000245. 